\title{
Nodular Pachymeningitis Associated With Relapsing Polychondritis and Crohn Disease Responsive to Adalimumab and Prednisone
}

Spencer K. Hutto, MD, Mary D. Maher, MD, Eli M. Miloslavsky, MD, and Nagagopal Venna, MD, MRCP

Neurol Neuroimmunol Neuroinflamm 2021;8:e1022. doi:10.1212/NXI.0000000000001022
Correspondence

Dr. Hutto

shutto@mgh.harvard.edu

\section{Abstract}

\section{Objectives}

To review the previous literature on the associations of pachymeningitis with Crohn disease (CD) and relapsing polychondritis (RP) and to describe a new case occurring in association with both in addition to highlighting its positive response to steroid and adalimumab treatment.

\section{Methods}

We review the patient's clinical presentation, diagnostic workup (serum and CSF testing), and MRI findings in detail and chronicle the response of the pachymeningitis to intensive immunotherapy. We contrast this case against previous reports of pachymeningitis occurring in association with RP and inflammatory bowel disease that were found on PubMed.

\section{Results}

Only 2 cases of ulcerative colitis and 5 cases of RP were found in association with pachymeningitis; there were no cases in association with CD. Our patient presented with symptoms isolated to a steroid-responsive headache in the setting of normal neurologic and rheumatologic examinations. Her preceding history was notable for long-standing CD and increasingly active symptoms referable to RP. Focal nodular pachymeningitis was seen overlying the left hemisphere on brain MRI. An extensive serum and CSF workup and body fluorodeoxyglucose-PET scan failed to identify an alternative etiology beyond her underlying autoimmune inflammatory disorders. After adding prednisone and adalimumab to her preexisting treatment of methotrexate, she responded dramatically both clinically and radiographically.

\section{Conclusions}

Although exceptionally rare, pachymeningitis may occur as a neuroinflammatory complication of $\mathrm{CD}$ and RP. 


\section{Glossary}

ANCA = antineutrophil cytoplasmic antibody; $\mathbf{C D}=$ Crohn disease; GPA = granulomatosis with polyangiitis; IBD = inflammatory bowel disease; IgG4 = immunoglobulin G type 4; IgG4-RD = IgG4-related disease; RP = relapsing polychondritis.

The meninges define the intrathecal sac enclosing the CNS and are composed of the dura, arachnoid, and pia mater. Pachymeningitis refers to isolated inflammation of the dura mater and is less common than leptomeningitis that involves the subarachnoid space. ${ }^{1}$ Rheumatologic disorders are uncommon but known causes of pachymeningitis, particularly immunoglobulin G type 4 (IgG4)-related disease (IgG4-RD), sarcoidosis, and GPA. ${ }^{2}$ By contrast, it has not been well documented in patients with relapsing polychondritis (RP) and Crohn disease (CD). We present our patient's presentation, rheumatologic history, and MRI findings of focal intracranial pachymeningitis and highlight its positive response to anti-inflammatory treatment.

\section{Case}

A 48-year-old woman with a history of RP and CD was referred for the evaluation of abnormal dural thickening overlying the left cerebral hemisphere found in the course of investigation of new-onset headache. She experienced 9 months of pain over the left side of the head associated with overlying scalp hypersensitivity. The headaches decreased in response to a short course of prednisone but returned 6 months later, quickly becoming persistent and refractory to common analgesics and gabapentin. She did not have neurologic symptoms, including seizures, focal sensory or motor symptoms, or changes in mental or cranial nerve functions.

General, rheumatologic, and neurologic examinations were normal. Although auricular and nasal erythema and edema were documented in previous examinations, she had no signs of chondritis or synovitis during the period of headache evaluation and treatment. Brain MRI performed 9 months into the course of her illness of increasing headaches showed smooth dural thickening and enhancement overlying the left cerebral hemisphere with focal nodular thickening and heterogeneous enhancement over the left frontal and temporal operculum. There was associated restricted diffusion corresponding to the region of pachymeningeal thickening and enhancement. The mass effect from the focal thickening effaced the adjacent sulci without evidence of vasogenic edema in the underlying parenchyma (figure, A.a-A.d).

ESR was elevated at $48 \mathrm{~mm} / \mathrm{h}$ and CRP at $42.1 \mathrm{mg} / \mathrm{L}$. Other pertinent negative or normal serum studies included testing for antineutrophil cytoplasmic antibody (ANCA), IgG subclasses (including IgG4), antinuclear antibody, Sjögren syndrome type A antigen, Sjögren syndrome type B antigen, angiotensin converting enzyme, HIV, Lyme, syphilis, and $\mathrm{T}$-spot for tuberculosis. CSF testing revealed 5 white blood cells $/ \mathrm{mm}^{3}$ (69\% lymphocytes), protein $31 \mathrm{mg} / \mathrm{dL}$, and glucose $72 \mathrm{mg} / \mathrm{dL}$ with an opening pressure of $27 \mathrm{~mm} \mathrm{H}_{2} \mathrm{O}$. Additional CSF testing was negative or normal, including

Figure MRIs Obtained Before (A.a-A.d) and After (B.a-B.d) 2 Months of Treatment With Adalimumab and Prednisone

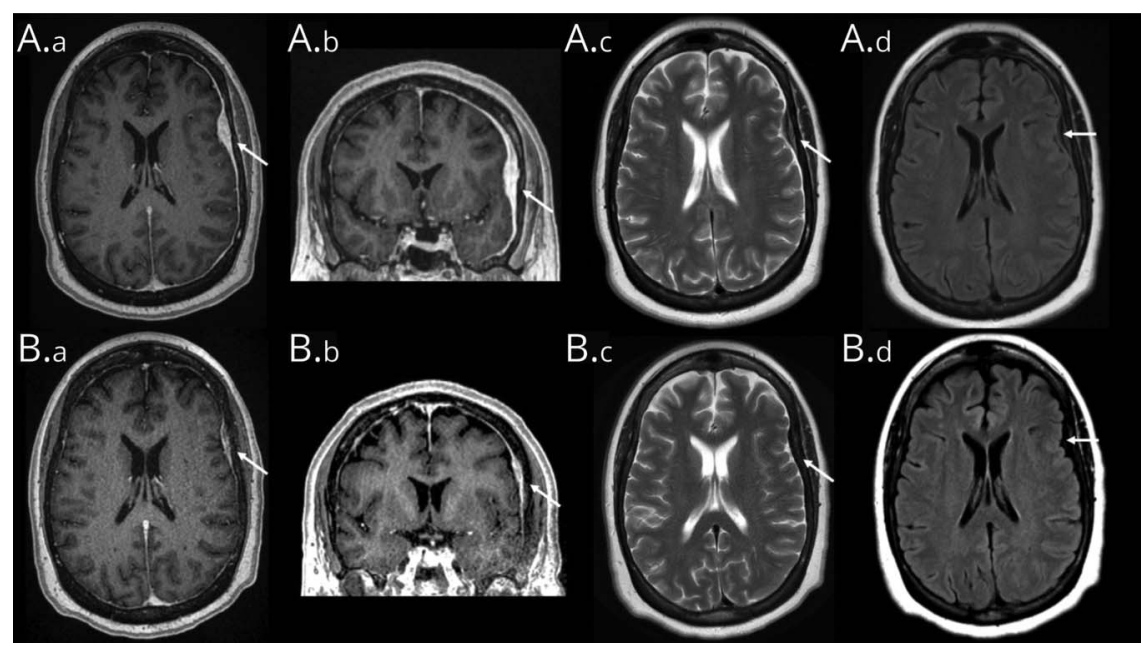

(A) T1-weighted sequences with contrast are seen in the axial (A.a and B.a) and coronal (A.b and B.b) planes and demonstrate smooth pachymeningeal thickening and enhancement over the left hemisphere with focal thickening and heterogeneous enhancement over the left inferior frontal gyrus and insula (A.a and A.b). The area of focal thickening demonstrates heterogeneous enhancement (A.a and A.b). The axial T2-weighted sequence shows the focally thickened dura is T2 isointense (A.c). The FLAIR sequence shows the mass effect from the thickened dura effaces adjacent sulci without vasogenic edema in the underlying frontal and temporal parenchyma (A.d). (B) After 2 months of treatment with prednisone and adalimumab (in addition to baseline methotrexate use), the smooth left hemispheric pachymeningeal thickening and enhancement has resolved, and there is minimal residual opercular focal thickening and enhancement (B.a and B.b). The focal thickening is no longer well visualized on T2-weighted images (B.C), and there is resolution of mass effect on the underlying parenchyma (B.d). The arrows emphasize the thickest focus of the nodular pachymeningitis, highlighting its appearance both before and after treatment. 
Table Summary of the Literature of Pachymeningitis Associated With IBD and RP

\begin{tabular}{|c|c|c|c|c|c|c|c|c|c|}
\hline Age/sex & $\begin{array}{l}\text { Rheumatologic } \\
\text { disorder }\end{array}$ & $\begin{array}{l}\text { Extraneural } \\
\text { involvement }\end{array}$ & Neurologic symptoms & $\begin{array}{l}\text { Location of } \\
\text { pachymeningitis }\end{array}$ & $\begin{array}{l}\text { Radiographic } \\
\text { morphology }\end{array}$ & Serum & CSF & Treatment & Outcome \\
\hline $42 / F^{5}$ & $\begin{array}{l}\text { UC: preceding } \\
\text { but duration NR }\end{array}$ & None & Headache & Diffuse & Smooth & $\begin{array}{l}\text { ANCA nuclear } \\
\text { staining }\end{array}$ & WBC 4, protein 7 & $\begin{array}{l}\text { CS, AZA, MMF, } \\
\text { TNFai, and } \\
\text { MTX }\end{array}$ & $\begin{array}{l}\text { Relapses with steroid } \\
\text { dependency }\end{array}$ \\
\hline $44 / F^{6}$ & UC: 16 y prior & Colon and oral & Headache & Diffuse & Smooth & PR3-ANCA & NR & $\begin{array}{l}\text { CS and } \\
\text { colectomy }\end{array}$ & $\begin{array}{l}\text { Relapses with steroid } \\
\text { dependency }\end{array}$ \\
\hline $48 / F$ & $\begin{array}{l}\text { CD: } 11 \text { y prior; } \\
\text { RP: } 6 \text { y prior }\end{array}$ & $\begin{array}{l}\text { Ears, eyes, nose, } \\
\text { and GE junction }\end{array}$ & $\begin{array}{l}\text { Headache and scalp } \\
\text { hypersensitivity }\end{array}$ & Focal convexal & Nodular & $\begin{array}{l}\text { ANCA and IgG4 } \\
\text { negative/ } \\
\text { normal }\end{array}$ & $\begin{array}{l}\text { WBC 5, protein } 31 \text {, } \\
\text { glucose } 72 \text {, and OCBs- } \\
\text { OP } 27\end{array}$ & $\begin{array}{l}\text { MTX, CS, and } \\
\text { TNFai }\end{array}$ & $\begin{array}{l}\text { Resolved headaches and } \\
\text { nearly complete resolution } \\
\text { on MRI }\end{array}$ \\
\hline $48 / F^{9}$ & $\mathrm{RP}-\mathrm{NR}$ & $\begin{array}{l}\text { Ear, nose, joints, } \\
\text { and kidneys }\end{array}$ & $\begin{array}{l}\text { Diplopia, hypoacusis, and } \\
\text { headache }\end{array}$ & Diffuse convexal & Smooth & PR3-ANCA & NR & CS and CYC & Good improvement \\
\hline $50 / F^{9}$ & $\mathrm{RP}-\mathrm{NR}$ & $\begin{array}{l}\text { Eyes, ear, trachea, } \\
\text { joints, and } \\
\text { kidneys }\end{array}$ & Left facial numbness & Infratentorial & Smooth & PR3-ANCA & Normal & CS & $\begin{array}{l}\text { Relapses with steroid } \\
\text { dependency }\end{array}$ \\
\hline $50 / F^{9}$ & $\mathrm{RP}-\mathrm{NR}$ & $\begin{array}{l}\text { Ear, nose, and } \\
\text { trachea }\end{array}$ & $\begin{array}{l}\text { Headache and cranial } \\
\text { polyneuropathy }\end{array}$ & Focal convexal, basal & Nodular & PR3-ANCA & NR & $\begin{array}{l}\text { CS, CYC, and } \\
\text { RTX }\end{array}$ & Poor response to CS \\
\hline $80 / M^{10}$ & RP: 3 wk after & Joints & $\begin{array}{l}\text { Headache, deafness, altered } \\
\text { facial sensation, and gait } \\
\text { disturbance }\end{array}$ & Diffuse & Smooth & ANCA negative & $\begin{array}{l}\text { WBC 57, protein 78, } \\
\text { and } \operatorname{lgG} \text { index } \uparrow\end{array}$ & CS & $\begin{array}{l}\text { Residual deafness and } \\
\text { improved imaging }\end{array}$ \\
\hline $81 / M^{6}$ & RP: 1.5 y prior & $\begin{array}{l}\text { Ears, eyes, and } \\
\text { trachea }\end{array}$ & $\begin{array}{l}\text { Cognitive impairment, } \\
\text { myoclonus, and rigidity }\end{array}$ & $\begin{array}{l}\text { Focal convexal, falx, and } \\
\text { marked deep white matter } \\
\text { changes }\end{array}$ & Smooth & ANCA negative & $\begin{array}{l}\text { WBC } 12, \text { protein } 65 \\
\text { glucose } 80 \text {, and OCBs+ }\end{array}$ & $\mathrm{CS}$ and $\mathrm{AZA}$ & Improved \\
\hline
\end{tabular}

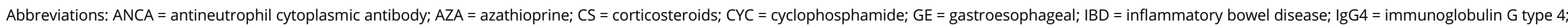

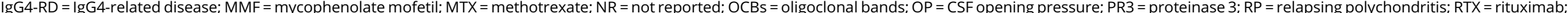
TNFai = tumor necrosis factor alpha inhibitor; UC = ulcerative colitis; $W B C=$ white blood cells

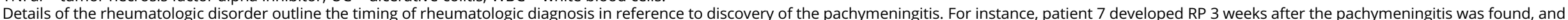

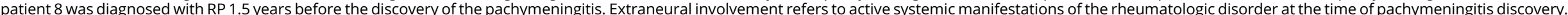

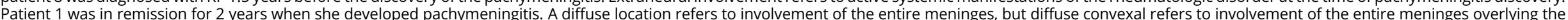
cerebral convexities. White blood cell counts are measured in cells $/ \mathrm{mm}^{3}$, and protein and glucose are measured in $\mathrm{mg} / \mathrm{dL}$. 
bacterial and fungal cultures, cytology for neoplastic cells, flow cytometry, IgG index and synthesis rate, and oligoclonal bands. An fluorodeoxyglucose-PET/CT of the body did not reveal any signs of neoplasm, sarcoidosis, or IgG4-RD, though did show increased radiotracer uptake at the gastroesophageal junction consistent with inflammation related to CD. A PET/ CT of the brain showed no abnormal uptake in the dural lesion or in the underlying cerebral tissue. A meningeal biopsy was offered, but the patient declined, preferring a trial of empiric treatment.

She was treated with prednisone (starting at $60 \mathrm{mg}$ daily and tapering down to $10 \mathrm{mg}$ daily by the time of reimaging) and adalimumab (TNF alpha inhibitor) for the following 2 months in addition to continuing preexisting methotrexate. The headache resolved promptly and remained in remission on clinical evaluation 2 months later. A follow-up brain MRI showed resolution of the smooth pachymeningeal thickening and enhancement and near-complete resolution of the focally thickened left frontal component (figure, B.a-B.d).

Her RP was diagnosed 6 years earlier with manifestations predominantly restricted to the nose (septum), eyes (scleritis and episcleritis), and ears (chondritis). Testing for other causes including ANCA-associated vasculitis, sarcoidosis, and IgG4$\mathrm{RD}$ was negative at diagnosis. Flares generally occurred once or twice per year. However, over the course of the year preceding headache onset, symptoms became gradually more severe and persistent, eventually requiring maintenance methotrexate for symptom control around the time of headache onset. Before the initial MRI, she was taking methotrexate $20 \mathrm{mg}$ weekly for 6 months. The patient had the diagnosis of $\mathrm{CD}$ for 11 years but had experienced only minimal abdominal symptoms, for which she was prescribed balsalazide. Family history was additionally significant for a number of rheumatologic illnesses, including psoriasis, CD, and uveitis.

\section{Discussion}

Pachymeningitis without leptomeningitis can occur either in the intracranial or in the intraspinal compartments. Compared with leptomeningitis, involvement confined to the dura is distinctly uncommon and is most often due to infectious, autoimmune, and neoplastic etiologies, although some cases remain idiopathic. ${ }^{1,3} \mathrm{~A}$ myriad of underlying diagnoses are possible, but the largest cohorts to date suggest that ANCAassociated vasculitis, IgG4-RD, sarcoidosis, tuberculosis, and the histiocytoses are most common. ${ }^{2}$

Neurologic complications of inflammatory bowel disease (IBD) are rare, occurring in roughly 3 percent of patients, and most commonly manifesting as myelopathy, myopathy, and peripheral neuropathy. ${ }^{4}$ To our knowledge, isolated pachymeningitis associated with IBD has only been reported twice in the absence of coexisting infection, both in cases of ulcerative colitis and not in association with $\mathrm{CD}$ (table). ${ }^{5,6}$ Pachymeningitis seems to be a rare neurologic complication of $\mathrm{RP}$; cranial nerve palsies, hemiparesis, and gait ataxia are reported more frequently. ${ }^{7}$ Meningoencephalitis has also been described, particularly of the limbic and basal ganglia regions. ${ }^{8}$ Of the 5 cases of pachymeningitis associated with RP indexed by PubMed, 3 were ANCA positive with $\mathrm{PR} 3$ specificity, suggesting that those cases may have been due to ANCA-associated vasculitis, which can also cause chondritis (table). ${ }^{9-11}$

The majority of previously reported cases of pachymeningitis associated with RP and/or IBD have had a relapsing course. Moreover, in this case, the pachymeningitis developed while the patient was on methotrexate. Therefore, we elected to treat with a combination of prednisone and escalation of her nonglucocorticoid regimen. TNF alpha inhibitors are a cornerstone of treatment for IBD and have been used in RP with some success, leading to adalimumab in combination with prednisone as the therapeutic choice in this case. ${ }^{12}$

Our patient's case highlights the possibility of pachymeningitis occurring in association with $\mathrm{CD}$ and expands the very limited literature of its association with $\mathrm{RP}$ in the absence of ANCA seropositivity. Given the more common association of cranial and spinal pachymeningitis with autoimmune connective tissue disorders, our patient's RP is likely the principal driving force for the dural connective tissue inflammation. This is further supported by its occurrence in the setting of long-standing symptomatic polychondritis while the $\mathrm{CD}$ had been comparatively clinically quiescent; signs of increased systemic polychondritis activity leading up to the development of cranial pachymeningitis; and by the rapid, robust, and sustained response to combination prednisone and adalimumab though the disease activity broke through methotrexate monotherapy.

As with our case, patients can have multiple autoimmune diseases, and therefore, an alternative consideration is that the pachymeningitis is a comorbid disease unrelated to RP or CD. The absence of pathology is a limitation in excluding IgG4$\mathrm{RD}$, but a biopsy would have been unlikely to definitively confirm our suspicion that the patient's underlying autoimmune diseases were linked pathophysiologically to the pachymeningitis because both the non-necrotizing granulomas seen in $\mathrm{CD}$ and the vasculitis in $\mathrm{RP}$ are nonspecific inflammatory findings often times seen in other conditions associated with pachymeningitis (sarcoidosis and ANCAassociated vasculitis). Similarly, CSF biomarkers for IgG-RD remain unproven and require further investigation of their clinical utility. ${ }^{13}$ Although possible, the likelihood of coexisting granulomatosis with polyangiitis (GPA) is felt to be low as almost all cases are ANCA seropositive, have at least some degree of systemic manifestations, and would be unexpected to respond to TNF alpha inhibitors. ${ }^{14-16}$

This case is the first in the literature to demonstrate the coexistence of RP and CD in association with pachymeningitis presenting as headaches. The case illustrates atypical 
involvement of the CNS and successful treatment with a combination of a TNF alpha inhibitor and steroids.

\section{Study Funding}

The authors report no targeted funding.

\section{Disclosure}

S.K. Hutto, M.D. Maher, E.M. Miloslavsky, and N. Venna report no disclosures relevant to the manuscript. Go to Neurology.org/NN for full disclosures.

\section{Publication History}

Received by Neurology: Neuroimmunology \& Neuroinflammation February 16, 2021. Accepted in final form April 5, 2021.

\section{Appendix Authors}

\begin{tabular}{lll}
\hline Name & Location & Contribution \\
\hline $\begin{array}{l}\text { Spencer K. } \\
\text { Hutto, MD }\end{array}$ & $\begin{array}{l}\text { Massachusetts } \\
\text { General Hospital, } \\
\text { Boston }\end{array}$ & $\begin{array}{l}\text { Design and conceptualized the } \\
\text { study; major role in the acquisition } \\
\text { of data; analyzed the data; and } \\
\text { drafted the manuscript for } \\
\text { intellectual content }\end{array}$ \\
$\begin{array}{lll}\text { Mary D. } \\
\text { Maher, MD }\end{array}$ & $\begin{array}{l}\text { Gassachusetts } \\
\text { Goneral Hospital, }\end{array}$ & $\begin{array}{l}\text { Major role in the acquisition of data; } \\
\text { interpreted the data; and revised the } \\
\text { manuscript for intellectual content }\end{array}$ \\
$\begin{array}{l}\text { Eli M. } \\
\text { Miloslavsky, } \\
\text { MD }\end{array}$ & $\begin{array}{l}\text { Massachusetts } \\
\text { General Hospital, }\end{array}$ & $\begin{array}{l}\text { Interpreted the data and revised the } \\
\text { manuscript for intellectual content }\end{array}$ \\
\hline $\begin{array}{l}\text { Nagagopal } \\
\text { Venna, MD, } \\
\text { MRCP }\end{array}$ & $\begin{array}{l}\text { Massachusetts } \\
\text { General Hospital, }\end{array}$ & $\begin{array}{l}\text { Interpreted the data and revised the } \\
\text { manuscript for intellectual content }\end{array}$ \\
\hline
\end{tabular}

\section{References}

1. Kupersmith MJ, Martin V, Heller G, Shah A, Mitnick HJ. Idiopathic hypertrophic pachymeningitis. Neurology. 2004;62(4):686-694.

2. Yonekawa T, Murai H, Utsuki S, et al. A nationwide survey of hypertrophic pachymeningitis in Japan. J Neurol Neurosurg Psychiatry. 2014;85(7):732-739.

3. Marrodan M, Bensi C, Alessandro L, Muggeri AD, Farez MF. Chronic and subacute meningitis: differentiating neoplastic from non-neoplastic etiologies. Neurohospitalist. 2018;8(4):177-182.

4. Lossos A, River Y, Eliakim A, Steiner I. Neurologic aspects of inflammatory bowel disease. Neurology. 1995;45(3 pt 1):416-421.

5. Xia Z, Chen-Plotkin A, Schmahmann JD. Hypertrophic pachymeningitis and cerebral venous sinus thrombosis in inflammatory bowel disease. J Clin Neurosci. 2010;17(11): 1454-1456.

6. Derbel A, Ghribi M, Frikha O, et al. Pachymeningitis in ulcerative colitis: accidental association? Asian J Res Rep Neurol. 2020;3(2):19-23.

7. Sundaram MB, Rajput AH. Nervous system complications of relapsing polychondritis. Neurology. 1983;33(4):513-515.

8. Wang $\mathrm{ZJ}, \mathrm{Pu} \mathrm{CQ}$, Wang $\mathrm{ZJ}$, et al. Meningoencephalitis or meningitis in relapsing polychondritis: four case reports and a literature review. J Clin Neurosci. 2011;18(12): 1608-1615.

9. Cañas CA, Díaz-Martínez JC, Tobón GJ. Combination of hypertrophic pachymeningitis, PR3-ANCA-positive vasculitis, and relapsing polychondritis. J Rheumatol. 2011;38(5):966-967.

10. Nakamura K, Sugaya K, Nakata Y, Shima S, Mutoh T, Nakano I. Hypertrophic pachymeningitis and encephalitis in a patient with relapsing polychondritis. Neurol Clin Neurosci. 2015;3(3):42-43.

11. Ushiyama S, Kinoshita T, Shimojima $\mathrm{Y}$, et al. Hypertrophic pachymeningitis as an early manifestation of relapsing polychondritis: case report and review of the literature. Case Rep Neurol. 2016;8(3):211-217.

12. Moulis G, Pugnet G, Costedoat-Chalumeau N, et al. Efficacy and safety of biologics in relapsing polychondritis: a French national multicenter study. Ann Rheum Dis. 2018; 77(8):1172-1178

13. Della Torre E, Bozzolo EP, Passerini G, Doglioni C, Sabbadini MG. IgG4-related pachymeningitis: evidence of intrathecal IgG4 on cerebrospinal fluid analysis. Ann Intern Med. 2012;156(5):401-403.

14. Finkielman JD, Lee AS, Hummel AM, et al. ANCA are detectable in nearly all patients with active severe Wegener's granulomatosis. Am J Med. 2007;120(7): 643.e9-643.e14.

15. Di Comite G, Bozzolo EP, Praderio L, Tresoldi M, Sabbadini MG. Meningeal involvement in Wegener's granulomatosis is associated with localized disease. Clin Exp Rheumatol. 2006;24(2 suppl 4):S60-S64.

16. The Wegener's Granulomatosis Etanercept Trial (WGET) Research Group. Etanercept plus standard therapy for Wegener's granulomatosis. N Engl J Med. 2005; 352(4):351-361. 


\title{
Neurology \\ Neuroimmunology \& Neuroinflammation
}

\author{
Nodular Pachymeningitis Associated With Relapsing Polychondritis and Crohn Disease \\ Responsive to Adalimumab and Prednisone \\ Spencer K. Hutto, Mary D. Maher, Eli M. Miloslavsky, et al. \\ Neurol Neuroimmunol Neuroinflamm 2021;8; \\ DOI 10.1212/NXI.0000000000001022
}

This information is current as of June 2, 2021

Updated Information \&

Services

References

Permissions \& Licensing

Reprints including high resolution figures, can be found at:

http://nn.neurology.org/content/8/5/e1022.full.html

This article cites 16 articles, 3 of which you can access for free at: http://nn.neurology.org/content/8/5/e1022.full.html\#\#ref-list-1

Information about reproducing this article in parts (figures,tables) or in its entirety can be found online at:

http://nn.neurology.org/misc/about.xhtml\#permissions

Information about ordering reprints can be found online:

http://nn.neurology.org/misc/addir.xhtml\#reprintsus

Neurol Neuroimmunol Neuroinflamm is an official journal of the American Academy of Neurology.

Published since April 2014, it is an open-access, online-only, continuous publication journal. Copyright

Copyright $\odot 2021$ The Author(s). Published by Wolters Kluwer Health, Inc. on behalf of the American

Academy of Neurology.. All rights reserved. Online ISSN: 2332-7812.

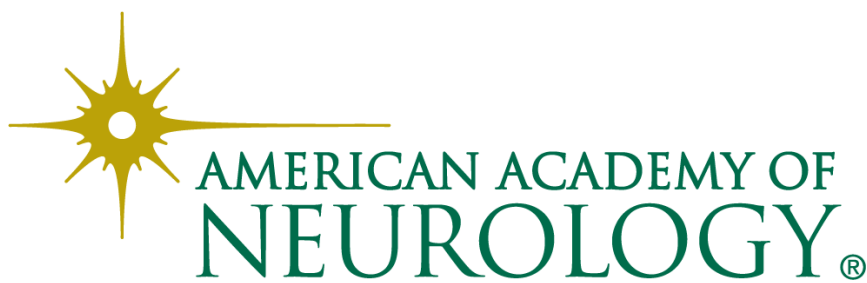

